\title{
ЭТНОПОЛИТИЧЕСКИЕ ПРОЦЕССЫ В РОССИИ
}

\section{Типология жителей российского мегаполиса по отношению к иноэтничным мигрантам ${ }^{1}$}

\author{
И.Б. БРИТВИНА*, Е.Л. МОГИЛЬЧАК**
}

\begin{abstract}
*Ирина Борисовна Бритвина - доктор социологических наук, профессор, кафедра интегрированных маркетинговых коммуникаций и брендинга, Уральский федеральный университет им. первого Президента России Б.Н. Ельцина. Адрес: 620002, Екатеринбург, ул. Мира, д. 19. E-mail: irina.britvina@urfu.ru

**Елена Львовна Могильчак - кандидат философских наук, доцент, Уральский федеральный университет им. первого Президента России Б.Н. Ельцина. Адрес: 620002, Екатеринбург, ул. Мира, д. 19. E-mail: e.l.mogilchak@urfu.ru
\end{abstract}

Цитирование: Бритвина И.Б., Могильчак Е.Л. (2018) Типология жителей российского мегаполиса по отношению к иноэтничным мигрантам // Мир России. Т. 27. № 1. C. 114-134. DOI: 10.17323/1811-038X-2018-27-1-114-134

В данной статье исследуется отночение к иноэтничным мигрантам, понимаемое как фактор аккультурации приезжих с учетом диспозиционной неоднородности принимающего сообщества. Эмпирической базой для анализа являлись результаты исследования жителей г. Екатеринбурга в возрасте 15 лет и старше. Проведен сравнительный анализ четырех типологических групп горожан с различными установками относительно мигрантов из Центральной Азии («непримиримые», «действенные благожелатели», «противоречивые» и «равнодушные»). Результаты получены с использованием кластерного анализа. В качестве классификационных признаков выступили 12 переменных, являюшихся прямыми индикаторами отношения к мигрантам. Особенности каждой типологической группы описаны с использованием индикаторов, которые отражают отношение к миграции как сочиильному процессу. Измерялись и диспозиции относительно мигрантов в их индивидуальном проявлении, включая приемлемость брачных отношений и личной дружбы с мигрантами. Выявлены два кластера, наиболее различающиеся по всему комплексу показателей. Основу различий между данными группами составляют иенностные особенности, которые косвенно проявляются в наличии или отсутствии неприязни к некоторым этносам.

\footnotetext{
1 Статья выполнена в рамках проекта РФФИ «Формирование идентичности мигрантов из стран Центральной Азии и
} россиян как проблема взаимоадаптации в условиях российского мегаполиса» (грант № №16-33-0010/17-ОГОН). 
Авторы приходят к выводу о существовании специффических причин формирования отношения к мигрантам в разных кластерах. Результаты опроса показали, что в центре формирования положительного или отрицательного отношения к приезжим в конкретном кластере может стоять широкое разнообразие сочиильных контактов с мигрантами, концентращия внимания на собственной этнической принадлежности, осознание угрозы реализаџии личных экономических интересов, этническая индифферентность.

Ключевые слова: миграция, принимающее сообщество, аккультурация, установки, ценности, интересы, кластерный анализ

Россия всегда была полиэтничной страной, однако процессы нарастания потоков иноэтничных мигрантов в начале XXI в. особым образом актуализировали проблематику отношения местного населения к иноэтничным мигрантам. Миграции населения - одна из важнейших проблем человечества, и рассматриваются они в различных науках не как механическое перемещение людей по территории, а как сложный социальный процесс, затрагивающий многие стороны жизни стран, континентов и планеты в целом. Глобальные изменения во всех сферах жизни мирового сообщества в конце XX - начале XXI в. привели к масштабному нарастанию миграционных потоков: большинство стран являются государствами или отпускающими мигрантов, или принимающими мигрантов, или транзитными. Россия одновременно выступает во всех трех ролях, и одной из самых актуальных сегодня проблем является проблема социально-культурной интеграции мигрантов. По косвенным данным, уровень «накопленной» в России иммиграции приближается к 30 млн чел. В связи с этим отношение россиян к внешней миграции в целом, а также к представителям ряда этнических групп в частности превратилось в важнейший фактор интеграции местного населения и приезжих. Опыт приема мигрантов странами Европейского союза существенно актуализирует этот аспект комплекса миграционных проблем.

Миграция населения является сложным и многогранным процессом. Исследователи крайне неоднозначно обосновывают теоретические и практические первопричины миграции и ее влияние на социально-политические и экономические процессы в различных регионах мира, по-разному трактуется и сущность этого понятия. Миграция представляет собой особую форму взаимодействия между субъектом миграции и той общностью, которая осуществляет прием мигранта, а также социальной группой, которую этот субъект покидает. Тем самым миграция - это трехстороннее взаимодействие, где важен каждый элемент. Изменения в образе жизни происходят не только у субъекта миграции: в результате миграционных процессов меняется образ жизни как отпускающей, так и принимающей мигрантов общности; у той и другой стороны происходят как количественные, так и качественные изменения. В результате миграции преображаются демографический состав как отпускающей, так и принимающей группы, профессиональная структура, квалификационные характеристики работающего населения, перестраивается этнический состав населения и др. В процессе перемещения меняются и сами мигранты, вынужденные приспосабливаться к образу жизни принимающего сообщества. 


\section{Обзор литературы}

Социологи отмечают, что интенсивные миграционные процессы приводят к существенным изменениям в отпускающих, принимающих и мигрирующих сообществах. Современная тенденция изучения внешних миграций такова, что при признании важности социальных аспектов необходимо оценивать их комплексно с учетом переплетения как социальных, так и экономических механизмов [Бритвина, Киблицкая 2004]. Тем более что миграция из стран Центральной Азии на территорию России связана в первую очередь с необходимостью получения средств существования [Thieme 2008]. Это особым образом актуализирует как необходимость изучения специфики миграций из Центральной Азии в Россию, так и выявление особенностей отношения жителей России к мигрантам.

В российской науке существует несколько конкурирующих между собой способов классификации, с помощью которых происходит выделение мигрантов как особой категории. Можно говорить о правовой, социальной и культурной классификации. Между ними происходит постоянное переключение: правовые признаки перекодируются в социальные, социальные - в культурные [Абашин 2012]. Кроме того, законодательная база в отношении внешних мигрантов в России находится в постоянной трансформации. Такая ситуация приводит к появлению «плавающих» критериев для оценки миграционных проблем. Таким образом, несмотря на продолжительность изучения, феномен миграции до сих пор нуждается в уточнении, т.к. не выработаны единые теоретические подходы ни к его анализу, ни к пониманию его сущности.

В последнее десятилетие в западной науке проблематика культурной совместимости местного населения и приезжих занимает важное место в исследованиях миграционных проблем. Ф. Шредер и М. Стефан-Эммрих, отстаивая применение термина «транслокальное» по сравнению с термином «транснациональное», пишут, что культурные и языковые границы могут иметь большее значение, чем национальные границы [Schröder, Stephan-Emmrich 2016]. Об этом в своей теории цивилизаций писал и С. Хантингтон [Huntington 1996].

Прикладной аспект проблематики культурной совместимости местного населения и приезжих - это проблема формирования общей социальной идентичности принимающего и мигрирующего сообществ. Так, бельгийские исследователи считают, что специфика восприятия мигрантами идентичности принимающей страны влияет на отношение жителей территории к иммигрантам [Roblain, Azzi, Licata 2016]. Тем более что, как справедливо отмечают Ф. Шредер и М. СтефанЭммрих, идентичность иноэтничных мигрантов имеет многоуровневый характер: мигранты имеют одновременно идентичность страны происхождения и страны приема [Schröder, Stephan-Emmrich 2016].

В процессах формирования общей идентичности россиян и внешних мигрантов большое значение имеет и многоуровневый характер идентичности жителей принимающей страны: так, российские исследователи отмечают у жителей России превалирование гражданской (государственно-гражданской) идентичности над этнической [Дробижева 2017, с. 8, 14].

С. Хантингтон, анализируя ситуацию в США, отмечал, что на идентичность огромное влияние имеет восприятие другими: «если большинство населения 
страны считает меньшинство отсталым и невежественным, то члены этого меньшинства воспримут это отношение, и оно превратится в часть их идентичности» [Хантингтон 2004, с. 53].

В настоящее время западные теоретики многосторонне исследуют различные аспекты влияния отношения принимающего сообщества на аккультурацию и натурализацию мигрантов. Г. Вайсман и Б. Ларсен на примере иммигрантов в Швеции показывают, что отношение к мигрантам со стороны местного населения влияет на доходы и в целом на качество жизни переселенцев [Waisman, Larsen 2016]. Опросы в США показали взаимосвязь восприятия местными жителями нелегальных иммигрантов с проблемой ощущения безопасности собственного существования [Simpson, Simpson, Cruz-Milan 2016]. Такую же взаимосвязь выделил и B.A. Понизовский, анализируя в рамках Европейского социального исследования (ESS) ситуацию в 25 странах [Ponizovskiy 2016]. С. Карлсен и Дж. Назроу, исследуя идентификации ряда этнических меньшинств в Великобритании, выявили проблему влияния социальной изоляции на способность групп этнических и религиозных меньшинств чувствовать себя частью принимающего сообщества. Их вывод сводится к тому, что более актуальной сегодня является проблема последствий маргинализации иноэтничных мигрантов в местных сообществах, чем проблема негативных итогов сохранения ими культурных традиций, т.к. это препятствует взаимной социальной интеграции [Karlsen, Nazroo 2015].

\section{Эмпирическая картина отношения к мигрантам в России}

За последнее десятилетие отношение к иноэтничным мигрантам в России существенно не изменилось: так, по данным Левада-Центра, положительные чувства к мигрантам (уважение либо симпатию) испытывает не более 10\% населения. Самая многочисленная категория выражает нейтральную позицию («не испытывают никаких чувств») - 56\% в 2006 г. и 60\% в 2016 г. [Пипия 2016]. Таким образом, показатели отношения к мигрантам на эмоциональном уровне достаточно стабильны. Это отражает влияние на аттитюды ценностных ориентаций, которые в течение жизни практически не меняются.

Л.Д. Гудков выделяет два типа защиты этнической общности путем проведения охранительной национальной политики [Гудков 2007, с. 60]. Первый тип - «мягкая» реакция на миграцию - представляет собой поощрение политики поддержки русской культуры и предоставления привилегий русскоязычным. Это касается доступа к образованию, карьеры, занятия ключевых позиций в бизнесе, органах правопорядка и армии, государственном управлении и т.п. Этот вариант выдвигают ресурсообеспеченные группы, которые стремятся закрепить свое особое преимущественное положение и в дальнейшем. Второй тип - изоляционистский, ориентированный на репрессивную политику по отношению к мигрантам и предполагающий запреты на занятие ими должностей в органах законодательной и исполнительной власти, ограничение районов проживания, а также установление административного надзора. Подобные установки чаще характерны для бедных в ресурсном плане групп.

И действительно, подавляющее большинство населения России (78\%) считает, что государство должно ограничивать приток иностранных мигрантов в страну. 
Однако это сочетается с достаточно благожелательным отношением к мигрантам на бытовом уровне: так, $61 \%$ опрошенных россиян указали, что не будут возражать против того, чтобы «мой ребенок дружил с детьми иностранных мигрантов» [Мигранты в России: эффекты присутствия 2016]. Также нужно отметить, что жители России признают не только недостатки, но и достоинства применения труда мигрантов. Отмечая влияние мигрантов на сдерживание роста зарплат россиян (71\%), более половины опрошенных считают, что благодаря мигрантам есть возможность получить более дешевые услуги [Мигранты в России: эффекты присутствия 2016]. Отмечаются такие деловые качества мигрантов в процессе труда, как честность, порядочность, надежность (72-77\%) [Мукомель 2011, с. 38].

Наивысший уровень различий во мнениях и оценках зафиксирован по таким важным вопросам, как необходимость сегрегации мигрантов и оценка связи роста преступности с наличием мигрантов. Эмпирические исследования показывают, что критическое отношение к иммигрантам зачастую основывается на этническом национализме, малом числе контактов с людьми разного этнического происхождения [Mierina, Koroleva 2015], а позитивное - на сочетании политического патриотизма и высокого дохода [Grigoryan 2016, p. 221]. Результаты российских исследований говорят о широком распространении негативного отношении к определенным, прежде всего к непривычным для данной принимающей среды, этническим группам [Кузнецов 2017, с. 73].

Позитивному отношению к мигрантам также способствуют диффузное расселение принимающего населения [Лапшина, Константинов 2016, с. 2], интериоризация мигрантами культуры принимающего сообщества [Roblain, Azzi, Licata 2016], приверженность жизненной ценности универсализма [Ponizovskiy 2016, p. 264]. В исследованиях отмечается, что низкий уровень жизни населения способствует негативному отношению к меньшинствам, а также значительно увеличивает ксенофобию [Mierina, Koroleva 2015, pp. 183-205]. Кроме того, связь качества жизни с критическим отношением к беженцам гораздо сильнее, чем его связь с размером доходов [Waisman, Larsen 2016].

Российские авторы отмечают, что россияне в целом принимают украинцев, молдаван, белорусов как потенциальных соседей и более враждебны по отношению к выходцам с Кавказа и Центральной Азии. Эта этническая иерархия разделяется всеми крупными этническими группами, населяющими Россию [Bessudnov 2016, p. 221; Мукомель 2017]. В.И. Мукомель представил интересную классификацию групп россиян по критерию толерантности: толерантные, колеблющиеся, гипоинтолерантные и гиперинтолерантные. Он пришел к выводу, что интолерантная позиция в первую очередь формируется под влиянием отсутствия положительных жизненных перспектив (социальной инклюзии) [Мукомель 2017].

Результаты исследований в Красноярском крае позволили выделить два типа образов мигрантов в массовом сознании жителей. Первый характеризуется агрессией, угрозой экономическому и культурному развитию края. Это подтверждается суждениями о том, что необходимо жестко контролировать приезд в Россию иностранных трудовых мигрантов (83\%); разрешать въезд в Россию только тем, кто знает русский язык и уважает русскую культуру (82\%); ограничивать количество иностранных трудовых мигрантов $(72 \%)$. Второй тип образа мигрантов включает позитивные характеристики, выраженные мнениями о том, что проживание на территории края представителей разных национальностей обогащает культуру; 
прибытие в Россию трудовых мигрантов из стран ближнего зарубежья неизбежно, с этим нужно смириться; что необходимо создавать условия для привлечения иностранных трудовых мигрантов в Россию [Федюкина 2015].

Таким образом, анализ научных источников и эмпирических данных показывает, что отношение россиян к иноэтничным мигрантам носит устойчивый негативно-безразличный характер. Россияне, с одной стороны, проблематизируют сферу бытовых межличностных контактов с иноэтничными мигрантами, не находя устойчивых поводов для постоянных взаимодействий с ними, что в свою очередь порождает проблемы интеграции и взаимоадаптации местного населения и приезжих. С другой стороны, жители России не проявляют полного отвержения контактов с приезжими в силу того, что мигранты объективно интегрированы как в сферу профессиональных взаимоотношений с россиянами, так и во взаимодействия на бытовом уровне.

Авторы статьи не обнаружили в отечественных научных источниках типологии групп россиян по отношению к мигрантам из стран Центральной Азии, составляющим большинство внешних мигрантов. Разработка такой типологии и стала целью данной статьи.

\section{Методология}

Екатеринбург, население которого в 2016 г. превысило 1,5 млн чел., является крупным российским мегаполисом, центром не только Свердловской области, но и Урала в целом. Географическое расположение Екатеринбурга на границе Европы и Азии обусловило повышенный приток мигрантов из стран Центральной Азии. Экономические характеристики города становятся привлекательными для внешних мигрантов и из других стран (Китай, Вьетнам, Турция и др.) в силу того, что Екатеринбург нуждается в рабочих кадрах в строительстве, транспорте, промышленности, обслуживании. Также город притягивает приезжих и с точки зрения предоставления качественных образовательных услуг, т.к. располагает более чем 30 вузами. Трудовая и образовательная внешняя миграция дают в сумме существенный ежегодный приток иноэтничных мигрантов, большинство которых прибывает из стран Центральной Азии: так, по данным Управления федеральной миграционной службы по Свердловской области, в 2014 г. по объемам привлечения иностранной рабочей силы область находилась на седьмом месте в Российской Федерации и на третьем месте в Уральском федеральном округе. В самом же Екатеринбурге оседает до 90\% мигрантов, въезжающих в Свердловскую область.

Наиболее плодотворный подход, позволяющий изучать проблемы интеграции россиян и приезжих, - социологический. Его особенностью является внимание к социальным взаимодействиям всех субъектов миграционного процесса: принимающего, отпускающего и мигрирующего сообществ. В настоящей статье использован конструктивистский подход: авторы рассматривают отношение россиян к иноэтничным мигрантам как фактор формирования общей социальной идентичности мигрирующего и принимающего сообществ. Вслед за В.А. Ядовым авторы разделяют два ключевых понятия: идентичность как четкое понимание человека о том, кем он является, кем являются «они» и «мы»; идентификация как процесс 
достижения этого понимания путем освоения, осмысления и выбора норм и правил различных социальных структур [Ядов 1995]. Идентификация, в отличие от идентичности, не подразумевает наличия «готовых» установок у субъекта, а предполагает поиск идентичности и ее постоянную трансформацию [Санина 2014]. В свою очередь успешность и эффективность формирования общей социальной идентичности (общегражданской идентичности) также влияют на отношение россиян к внешним мигрантам в силу того, что установка на принятие мигрантов как «своих» формируется и укрепляется постепенно и поэтапно, базируясь на «успехах» предыдущих этапов.

В целях изучения отношения к иноэтничным мигрантам из стран Центральной Азии в мае 2016 г. авторами статьи были опрошены 485 жителей Екатеринбурга. Отбор респондентов осуществлялся по квотной выборке с учетом пола, возраста и районов проживания населения города. Были выделены три группы индикаторов отношения к мигрантам.

Первая группа включала такие показатели, как отношение к приему нерусских мигрантов и увеличению их числа, к целесообразности получения мигрантами российского гражданства; оценка миграции из стран Центральной Азии в качестве проблемы. Данные индикаторы отражают отношение к миграции как социальному процессу. В группу прямых индикаторов также вошли следующие переменные: оценка давно живущих в городе мигрантов как «своих» или «чужих»; определение степени привыкания к присутствию в городе большого числа мигрантов; число видов помощи, которые местные жители готовы оказать приезжим.

Индикаторы, входящие во вторую группу, касались восприятия респондентами приезжих из Центральной Азии и измерялись как индексы социальной дистанции. Индексы социальной дистанции являлись результатом работы с дихотомическими переменными и рассчитывались как число положительных ответов на вопросы о приемлемости брачных, дружеских, соседских отношений с выходцами из Центральной Азии, а также отношений коллег по работе, сограждан, жителей одного города. Оказалось, чем выше значение индекса, тем социальная дистанция с мигрантами ближе, что указывает на более благожелательное к ним отношение. Характер задаваемых вопросов соответствовал в большей мере вопросам, применяемым Эмори Богардусом при изучении социальной дистанции. Количество индексов было равно числу оцениваемых народов стран Центральной Азии: таджиков, туркменов, узбеков, казахов, киргизов.

Переменные, входящие как в первую, так и во вторую группу, являются прямыми индикаторами отношения к мигрантам и миграционным процессам. Кумулятивность полученных шкал проверялась при помощи коэффициента воспроизводимости по методике Л. Гуттмана. При критическом значении 0,9 он составил от 0,978 для социальной дистанции по отношению к казахам до 0,988 - к туркменам. Следовательно, полученные шкалы имеют выраженный кумулятивный характер, что указывает на высокий уровень надежности измерения.

В третью группу входили косвенные индикаторы отношения к мигрантам. Процедура их формирования включала подсчет числа выбранных вариантов ответа на вопросы множественного выбора. В данную группу были включены следующие признаки: число требований к мигрантам из стран Центральной Азии; число групп иноэтничных мигрантов, с которыми устанавливались контакты; число характеристик мигрантов, принимаемых в расчет при их оценивании; число обстоятельств, 
объединяющих обследуемых с мигрантами; число используемых источников информации о мигрантах. Таким образом, было получено 12 переменных: 7 прямых индикаторов отношения к мигрантам из стран Центральной Азии и 5 косвенных.

Цель метода кластерного анализа состояла в разделении выборочной совокупности на группы, внутренне однородные по классификационным переменным и имеющие особенности при сравнении с другими кластерами. В качестве классификационных выступили 12 переменных, являющихся прямыми индикаторами отношения к мигрантам из стран Центральной Азии. Процедура кластерного анализа осуществлялась методом k-средних при помощи компьютерной программы обработки данных SPSS. Вследствие разного количества значений классификационных переменных они были подвергнуты стандартизации. Используемая количественная мера при формировании кластеров - квадрат евклидова расстояния. Полученные кластеры сравнивались не только по значениям классификационных признаков, но и по признакам, являющимся косвенными индикаторами отношения к мигрантам. При сравнительном анализе также выявлялись социально-культурные особенности жителей города, входящих в классификационные группы. Предполагалось, что кластеры, образующие выборочную совокупность, будут отличаться как по интенсивности проявления положительного/отрицательного отношения к мигрантам, так и по социально-культурным особенностям.

\section{Результаты исследования}

Существование типологических групп жителей Екатеринбурга формирует общую картину отношения к мигрантам и к миграционным проблемам в целом. Прежде чем описывать выявленные типологические группы, покажем общие итоги проблематизации присутствия иноэтничных мигрантов из стран Центральной Азии со стороны жителей Екатеринбурга. Половина опрошенных критически относится к тому, что Россия постоянно принимает нерусских мигрантов из стран Центральной Азии (51,3\%). 60,2\% проявили негативное отношение к росту числа мигрантов в Екатеринбурге. На это влияет тот факт, что россияне не понимают целесообразности приема такого большого количества приезжих из Центральной Азии: более половины опрошенных в Екатеринбурге $(56,3 \%)$ считают, что рост числа мигрантов - это проблема, которая обостряет многие другие городские проблемы; подавляющее число респондентов $(70,9 \%)$ ничего не знают о культурных особенностях мигрантов из стран Центральной Азии, а более половины опрошенных $(56,3 \%)$ имеют о них больше отрицательной информации, чем положительной. Из вышеприведенных данных вполне очевидно, что респонденты слабо настроены на интеграцию с приезжими. Подавляющее большинство опрошенных жителей Екатеринбурга не готовы менять свои культурные привычки ради безопасного сосуществования с иноэтничными мигрантами (75\%), т.е. они ждут видимых изменений со стороны приезжих. Это актуализировано в перечне требований со стороны принимающего сообщества, среди которых превалируют запросы, связанные с безопасностью и культурой: соблюдение российских законов $(67,7 \%)$, знание русского языка $(63,6 \%)$, следование культурным нормам нашей страны $(63,6 \%)$, причем позиции мужчин и женщин практически не отличаются (таблица 1). 
Таблица 1. Требования к нерусским мигрантам из стран Центральной Азии, \% от числа опрошенных

\begin{tabular}{|l|c|c|c|}
\hline \multirow{2}{*}{ Перечень требований } & \multicolumn{3}{|c|}{ Пол } \\
\cline { 2 - 4 } & Мужской & Женский & В целом \\
\hline Соблюдать наши законы & 69,1 & 66,4 & 67,7 \\
\hline Знание русского языка & 65,0 & 62,5 & 63,6 \\
\hline Соблюдать культурные нормы, принятые в России & 62,3 & 64,8 & 63,6 \\
\hline В общественных местах говорить только на русском языке & 29,5 & 29,2 & 29,4 \\
\hline Молодежь из этих стран в России не должна вести себя вызывающе & 27,3 & 27,3 & 27,3 \\
\hline Не создавать при расселении «этнические кварталы» & 22,3 & 19,4 & 20,7 \\
\hline $\begin{array}{l}\text { Не претендовать на рабочие и учебные места, } \\
\text { которые могли бы занять россияне }\end{array}$ & 13,6 & 23,3 & 18,8 \\
\hline $\begin{array}{l}\text { Не требовать особых условий для соблюдения своих религиозных } \\
\text { обрядов }\end{array}$ & 15,5 & 19,0 & 17,3 \\
\hline $\begin{array}{l}\text { Не демонстрировать свои культурные отличия в одежде, поведении, } \\
\text { обычаях }\end{array}$ & 15,0 & 12,3 & 13,5 \\
\hline Другие требования & 2,3 & 2,0 & 2,1 \\
\hline Не знаю & 2,7 & 1,6 & 2,1 \\
\hline Нет ответа & 0,5 & 0,0 & 0,2 \\
\hline
\end{tabular}

*Респонденты могли выбирать несколько вариантов ответа.

Но и при выполнении этих условий лишь треть опрошенных (30,7\%) готовы считать приезжих из этих стран «своими», при этом более трети однозначно считают их «чужими» $(33,4 \%)$, остальные затруднились ответить на этот вопрос, что также наталкивает на размышления. Менее половины респондентов лишь частично привыкли к присутствию мигрантов из стран Центральной Азии, т.к. эта ситуация их «напрягает» $(48,6 \%)$, причем пятая часть опрошенных совершенно не могут привыкнуть к присутствию мигрантов в Екатеринбурге (19,7\%). Можно видеть, что среди мужчин и женщин практически одинаковы доли тех, кто «вполне приспособился» к присутствию мигрантов, однако среди женщин $(52,6 \%)$ больше тех, кто привык частично, а среди мужчин $(24,1 \%)$ - больше тех, кто не может примириться с присутствием иноэтничных мигрантов (таблица 2).

Можно утверждать, что ситуация в Екатеринбурге является типичной для российского мегаполиса. Представив общую картину отношения к мигрантам жителей Екатеринбурга, остановимся на некоторых факторах, оказывающих влияние на данное обстоятельство. Мы выяснили, что социально-демографические факторы не оказывают влияния на отношение к мигрантам, и основными остаются поведенческий и национально-культурный факторы. На поведенческом уровне нами замерялись наличие и широта контактов с мигрантами, на национально-культурном - осознание своей национальности. 
Таблица 2. Степень привыкания к присутствию большого числа мигрантов из стран Центральной Азии в группах мужчин и женщин

\begin{tabular}{|l|c|c|c|}
\hline \multirow{2}{*}{ Вариант ответа } & \multicolumn{3}{|c|}{ Пол } \\
\cline { 2 - 4 } & Мужской & Женский & В целом \\
\hline Да, я вполне привык(ла) & 29,5 & 30,0 & 29,8 \\
\hline Частично привык(ла) & 44,1 & 52,6 & 48,6 \\
\hline Я совершенно не могу привыкнуть к их присутствию в городе & 24,1 & 15,8 & 19,7 \\
\hline Нет ответа & 2,3 & 1,6 & 1,9 \\
\hline Итого & $\mathbf{1 0 0 , 0}$ & $\mathbf{1 0 0 , 0}$ & $\mathbf{1 0 0 , 0}$ \\
\hline
\end{tabular}

Наши данные свидетельствуют о том, что фактор контактов положительно коррелирует со степенью благоприятности диспозиции относительно мигрантов. Чем шире круг контактов с мигрантами, тем чаще отношения личной дружбы с ними рассматриваются как приемлемые, больше видов помощи, которую готовы предоставить им жители города, реже встречается отрицательное отношение к предоставлению гражданства и указание на низкий уровень культуры приезжих: так, респонденты, которые общаются с представителями данных народов, почти в три раза реже выступают против получения ими российского гражданства в сравнении с теми, у кого в круге общения выходцы из Центральной Азии отсутствуют. В группе общающихся также меньше противников постоянного приема нерусских мигрантов из стран Центральной Азии, роста числа мигрантов в городе, меньше осознающих мигрантов как «чужих». Особо нужно отметить, что среди имеющих контакты с мигрантами всего лишь 8,5\% указали, что совершенно не могут привыкнуть к присутствию в городе большого числа лиц данных национальных групп; среди не имеющих контактов данный показатель составил $39 \%$.

Фактор осознания своей национальности, наоборот, негативно влияет на степень благоприятности отношения к мигрантам. Те жители города, кто полностью согласны с суждением «я постоянно помню о своей национальности», в большей степени отрицательно относятся к постоянному приему Россией мигрантов из Центральной Азии, росту их числа в Екатеринбурге, предоставлению им гражданства. Отношения личной дружбы с приезжими здесь реже считаются допустимыми. Для каждого второго респондента данной категории мигранты из Центральной Азии, даже прожившие в России несколько лет, все равно останутся «чужими». Среди тех, кто не согласился с точкой зрения, что постоянно помнит о своей национальности, мигранты являются «чужими» лишь для 5\% опрошенных. В этой группе больше тех, кто привык к присутствию в городе большого числа мигрантов из Центральной Азии. Такое мнение встречается здесь почти в три раза чаще, чем среди тех, кто постоянно помнит о своей национальности. Нужно особо отметить, что степень согласия с суждением «я постоянно помню о своей национальности» положительно коррелирует с наличием неприязни к некоторым национальностям. Это может указывать на наличие у некоторых групп опрошенных национального предубеждения, становящегося фактором негативного отношения к мигрантам. 
Кроме того, важно сказать, что установка «постоянно помнить о своей национальности» свидетельствует об активной солидаризации по этническому признаку, т.е. она является элементом сильной этнической идентичности.

\section{Таблица 3. Индексы отношения населения города Екатеринбурга к мигрантам из Центральной Азии}

\begin{tabular}{|l|c|c|c|c|}
\hline \multirow{2}{*}{ Индексы } & \multicolumn{4}{|c|}{ Кластеры } \\
\cline { 2 - 5 } & $\begin{array}{c}\text { «Неприми- } \\
\text { римые» }\end{array}$ & $\begin{array}{c}\text { «Действен- } \\
\text { ные благо- } \\
\text { желатели» }\end{array}$ & $\begin{array}{c}\text { «Противо- } \\
\text { речивые» }\end{array}$ & $\begin{array}{c}\text { «Равнодуш- } \\
\text { ные» }\end{array}$ \\
\hline $\begin{array}{l}\text { Индекс социальной дистанции } \\
\text { по отношению к таджикам }\end{array}$ & 0,29 & 4,07 & 3,38 & 0,94 \\
\hline $\begin{array}{l}\text { Индекс социальной дистанции } \\
\text { по отношению к узбекам }\end{array}$ & 0,36 & 4,11 & 3,30 & 1,00 \\
\hline $\begin{array}{l}\text { Индекс социальной дистанции } \\
\text { по отношению к киргизам }\end{array}$ & 0,38 & 4,15 & 3,34 & 1,30 \\
\hline $\begin{array}{l}\text { Индекс социальной дистанции } \\
\text { по отношению к туркменам }\end{array}$ & 0,40 & 4,07 & 3,32 & 1,06 \\
\hline $\begin{array}{l}\text { Индекс социальной дистанции } \\
\text { по отношению к казахам }\end{array}$ & 1,09 & 4,31 & 3,65 & 2,00 \\
\hline $\begin{array}{l}\text { Число видов помощи, которые готовы } \\
\text { оказать мигрантам }\end{array}$ & 0,25 & 2,72 & 0,90 & 0,49 \\
\hline $\begin{array}{l}\text { Число факторов увеличения похожести } \\
\text { мигрантов и местных }\end{array}$ & 1,63 & 3,59 & 2,89 & 1,86 \\
\hline $\begin{array}{l}\text { Число используемых источников } \\
\text { информации о мигрантах }\end{array}$ & 2,23 & 2,41 & 2,12 & 1,50 \\
\hline $\begin{array}{l}\text { Число характеристик мигрантов, } \\
\text { определяющих отношение к ним }\end{array}$ & 2,39 & 2,01 & 2,13 & 1,71 \\
\hline $\begin{array}{l}\text { Число групп мигрантов, } \\
\text { с которыми контактирует }\end{array}$ & 1,27 & 2,17 & 1,63 & 1,09 \\
\hline Число требований к мигрантам & 3,42 & 3,21 & 3,52 & 2,77 \\
\hline
\end{tabular}

С целью выявления типологических групп на основе индикаторов отношения к нерусским мигрантам из Центральной Азии нами был проведен кластерный анализ, в результате которого было выделено четыре кластера. Отметим, что максимальная доля населения (34,9\%) относится к первому кластеру - группе с выраженным отрицательным отношением к мигрантам. Минимальный процент жителей Екатеринбурга $(15,1 \%)$ входит в кластер, характеризующийся благожелательным отношением к приезжим, что проявляется не только на уровне мнений и диспозиций, но и в поведении респондентов. Кластер с противоречивым отношением к мигрантам и кластер «равнодушных» составляют в общей сложности около половины опрошенных, обе категории численно примерно равны, т.е. распределение населения по кластерам является хотя и не полностью равномерным, но, тем не менее, значительно дифференцированным. Индекс качественной вариации составил 0,83 
при интервале изменения от 0 до 1. Это говорит об отсутствии кластера, который выступает в качестве явного лидера или очевидного аутсайдера по числу элементов.

Опишем особенности полученных нами классификационных групп. Первый кластер - «непримиримые» (169 чел. - 34,9\%) - характеризуется ярко выраженным критическим отношением к мигрантам (как на личностном уровне, так и на уровне признания миграции как социального процесса). Для данной группы характерно негативное отношение к принятию мигрантов и росту их численности в городе, восприятие миграции как проблемы, обостряющей другие проблемы горожан: так, к росту в Екатеринбурге числа мигрантов отрицательно относится 99,4\%, к их постоянному приему - 93\% от численности данной классификационной группы. Рост числа мигрантов из Центральной Азии в 86\% случаев считается проблемой, которая обостряет другие проблемы.

«Непримиримые» гораздо реже, чем респонденты других кластеров, считают, что мигрантов, проживших в стране несколько лет, можно считать «своими». Их отношение к предоставлению гражданства является неблагоприятным значительно чаще, чем в других кластерах. Почти половина опрошенных считают помощь мигрантам ненужной, указывают меньшее число обстоятельств нарастания «похожести» местных жителей и приезжих. Для данной группы характерна большая социальная дистанция со всеми лицами нерусского населения стран Центральной Азии: таджиками, киргизами, узбеками, казахами, туркменами (таблица 3). Так, личная дружба с ними оценивается как приемлемая всего в $14 \%$ случаев, лишь каждый пятый опрошенный готов принять их в качестве коллег по работе (таблиц̧а 4). Это соответствует реальной картине общения данной категории респондентов: друзья, являющиеся выходцами из Центральной Азии, встречаются в круге общения «непримиримых» в 2,4\% случаев, коллеги по работе в 8,5\%. Для указанного кластера свойственно максимально развитое осознание своей национальности и необходимости ведущей роли русской культуры, приверженность православной вере. Это сопровождается более частым неприязненным отношением к представителям некоторых наций, высокой социальной дистанцией с приезжими из Центральной Азии. Мало зная о культурных особенностях мигрантов, «непримиримые» оценивают их уровень культуры как низкий, чаще других считают, что станет лучше, если мигранты не будут сохранять свою культуру, а растворятся в российской. Респонденты данной группы зачастую получают отрицательную, а не положительную информацию о мигрантах, которая поступает к ним не из личных контактов, а, как правило, из средств массовой коммуникации.

Второй кластер - «действенные благожелатели» (75 чел. - 15,5\%). Действенность представителей этого кластера проявляется в обширном опыте общения с мигрантами, в готовности оказать им помощь по некоторым вопросам. Естественным следствием или предпосылкой «позитивной действенности» является положительное отношение как к пребыванию мигрантов в Екатеринбурге, так и готовность воспринять их в качестве брачных партнеров или друзей: так, 82\% респондентов, входящих в данный кластер, считают приемлемой личную дружбу с лицами хотя бы одной национальной группы мигрантов из Центральной Азии; они преимущественно готовы в деловых отношениях общаться с мигрантами как с партнерами, а в 93\% случаев не возражали бы против предоставления им гражданства. «Действенные благожелатели» указывают большее число обстоятельств, которые могут способствовать «похожести» местных жителей и приезжих, чаще 


\section{Таблица 4. Показатели отношения к мигрантам в кластерах, \% от числа опрошенных в каждом кластере}

\begin{tabular}{|c|c|c|c|c|}
\hline \multirow[b]{2}{*}{ Составляющие отношения к мигрантам } & \multicolumn{4}{|c|}{ Кластеры } \\
\hline & $\begin{array}{l}\text { «Неприми- } \\
\text { римые» }\end{array}$ & $\begin{array}{l}\text { «Действен- } \\
\text { ные благо- } \\
\text { желатели» }\end{array}$ & $\begin{array}{l}\text { «Противо- } \\
\text { речивые» }\end{array}$ & $\begin{array}{l}\text { «Равнодуш- } \\
\text { ные» }\end{array}$ \\
\hline $\begin{array}{l}\text { Относится положительно к тому, что } \\
\text { Россия постоянно принимает нерусских } \\
\text { мигрантов из Центральной Азии }\end{array}$ & 0,6 & 52,0 & 0,0 & 11,2 \\
\hline $\begin{array}{l}\text { Относится положительно к росту числа } \\
\text { нерусских мигрантов из Центральной } \\
\text { Азии }\end{array}$ & 0,0 & 45,3 & 0,0 & 7,2 \\
\hline $\begin{array}{l}\text { Вполне привык к присутствию в городе } \\
\text { большого числа таджиков, казахов, } \\
\text { киргизов, туркменов }\end{array}$ & 2,4 & 82,7 & 27,0 & 37,6 \\
\hline $\begin{array}{l}\text { Привык частично к присутствию в городе } \\
\text { большого числа выходцев из Центральной } \\
\text { Азии, так как их присутствие его иногда } \\
\text { напрягает }\end{array}$ & 51,5 & 17,3 & 71,3 & 45,6 \\
\hline $\begin{array}{l}\text { Совершенно не может привыкнуть } \\
\text { к присутствию в городе большого числа } \\
\text { выходцев из Центральной Азии }\end{array}$ & 43,8 & 0,0 & 1,7 & 12,8 \\
\hline $\begin{array}{l}\text { Считает, что рост числа мигрантов - } \\
\text { не проблема, а решение других проблем } \\
\text { для города }\end{array}$ & 3,0 & 72,0 & 13,0 & 35,2 \\
\hline $\begin{array}{l}\text { Считает, что рост числа мигрантов - } \\
\text { проблема, которая усугубляет другие } \\
\text { проблемы }\end{array}$ & 85,8 & 14,7 & 76,5 & 22,4 \\
\hline $\begin{array}{l}\text { Считает, что не нужно разрешать } \\
\text { мигрантам из Центральной Азии получать } \\
\text { российское гражданство }\end{array}$ & 59,2 & 4,0 & 8,7 & 15,2 \\
\hline $\begin{array}{l}\text { Считает, что мигранты из Центральной } \\
\text { Азии вполне свои, если освоились } \\
\text { и не нарушают наших законов }\end{array}$ & 3,6 & 64,0 & 60,0 & 20,8 \\
\hline $\begin{array}{l}\text { Приемлемы брачные отношения } \\
\text { с представителями хотя бы одной } \\
\text { национальной группы мигрантов }\end{array}$ & 5,0 & 48,6 & 38,9 & 6,7 \\
\hline $\begin{array}{l}\text { Приемлема личная дружба } \\
\text { с представителями хотя бы одной } \\
\text { национальной группы мигрантов }\end{array}$ & 13,8 & 81,9 & 62,8 & 24,4 \\
\hline $\begin{array}{l}\text { Приемлемы отношения с представителями } \\
\text { хотя бы одной национальной группы } \\
\text { мигрантов в качестве коллег по работе }\end{array}$ & 21,4 & 87,5 & 73,5 & 38,7 \\
\hline $\begin{array}{l}\text { Известно больше отрицательной } \\
\text { информации о мигрантах } \\
\text { из Центральной Азии }\end{array}$ & 78,1 & 18,7 & 62,6 & 42,4 \\
\hline $\begin{array}{l}\text { Есть в кругу людей, с которыми } \\
\text { контактирует, представители мигрантов } \\
\text { из Центральной Азии }\end{array}$ & 29,6 & 78,7 & 56,5 & 30,4 \\
\hline $\begin{array}{l}\text { Были факты оказания помощи мигрантам } \\
\text { из Центральной Азии }\end{array}$ & 16 & 68 & 33 & 10,4 \\
\hline
\end{tabular}


демонстрируют привыкание к большому числу мигрантов в городе и считают, что при длительном проживании мигранта в городе его можно считать «своим». В качестве наиболее распространенных факторов нарастания «похожести» называются совместная работа и род занятий. В 82,7\% случаев «действенные благожелатели», наиболее лояльные по отношению к выходцам из Центральной Азии, полагают, что вполне привыкли к присутствию в городе большого числа выходцев из Центральной Азии (таблица 4). Около 68\% ее состава имели опыт оказания помощи приезжим, они выражают готовность оказать мигрантам максимальное число видов помощи - содействие в поиске жилья, работы, предоставление одежды, предметов быта, нужной информации для адаптации в России. Представители этого кластера лучше знают культуру мигрантов и чаще допускают ее сохранение, а не растворение в русской культуре, готовы меняться под влиянием новых культурных норм, которые несут с собой мигранты. Понимание и принятие иноэтничной культуры связаны в том числе и с высоким разнообразием и плотностью контактов с мигрантами: в круг общения входят коллеги по работе, друзья, соседи по дому, по двору, причем соседи входят в круг общения минимум в 1,5 раза чаще, чем в других кластерах, друзья - минимум в 2,2 раза. Респонденты, входящие в кластер «действенных благожелателей», имеют сходство с кластером «противоречивых» по такому признаку, как наличие мигрантов среди коллег по работе: так, в данных группах примерно каждый пятый опрошенный общается с мигрантами из Центральной Азии в трудовом коллективе. Следствием этого является более частое указание на совместную работу и один род занятий в качестве обстоятельств, объединяющих мигрантов с местным населением и благоприятствующих нарастанию «похожести» местных жителей и приезжих.

Третий кластер: «противоречивые» (116 чел. - 23,8\%). По позитивности отношения к народам Центральной Азии они близки к «действенным благожелателям». Представители этого кластера имеют достаточно выраженную готовность ввести мигрантов в круг близких людей, оказать помощь в решении отдельных проблем, не против предоставления приезжим российского гражданства. Для 63\% опрошенных из этого кластера приемлема личная дружба с выходцами из некоторых центрально-азиатских групп, а для 39\% - брачные отношения. Как и в кластере «действенных благожелателей», здесь часто отмечается, что при длительном проживании мигранта в городе его можно считать «своим». Но степень привыкания этой группы к мигрантам не столь велика: 71\% опрошенных указали, что привыкли лишь частично к присутствию в городе выходцев из Центральной Азии, так как их присутствие иногда «напрягает» (таблица 4). В 90\% случаев «противоречивые» критически относятся к росту числа мигрантов, а 77\% из них рассматривают миграцию из Средней Азии как проблему, которая осложняет жизнь горожанам. Нужно также отметить, что экономические проблемы для местного населения, связанные с приездом мигрантов, упоминаются в данной группе чаще, чем в других кластерах. Мы наблюдаем, таким образом, противоречие между личностным восприятием представителями данного кластера народов Центральной Азии и их миграцией на территорию России, выступающей в качестве социального процесса.

Рассмотрим анализируемый кластер «противоречивых» в сравнении с вышеуказанными типологическими группами. Несмотря на сходство с группой «действенных благожелателей» по показателям позитивного отношения к мигрантам, здесь в два раза реже встречаются люди, имевшие опыт оказания 
помощи мигрантам, и в три раза реже - указавшие на то, что вполне привыкли к присутствию в городе большого числа мигрантов. Чаще, чем в кластере «действенных благожелателей», уровень культуры мигрантов из Центральной Азии оценивается как низкий, также в большей степени указывается на владение информацией о мигрантах, которая является скорее отрицательной, чем положительной. Однако обладание негативными сведениями о мигрантах не сочетается в данном кластере с таким же распространенным мнением о низком уровне культуры приезжих, как у «непримиримых». Как и в кластере «непримиримых», в группе «противоречивых» чаще, чем в других кластерах, интересуются историей и литературой своего народа, осознают необходимость ведущей роли русской культуры (таблица 5). В большинстве случаев здесь зафиксирована неготовность меняться под влиянием новых культурных норм, которые несут с собой мигранты. Коренное отличие данных групп - в значительно меньшей выраженности в кластере «противоречивых» внимания к собственной национальности и большем внимании к культуре других наций: так, в кластере «противоречивых» респонденты, отметившие, что никакие национальности не вызывают у них неприязни, встречаются в три раза чаще, чем в группе «непримиримых»; в полтора раза меньше доля тех, кто постоянно помнит о своей национальности, но больше знакомых с культурными особенностями народов Центральной Азии. Таким образом, в данной группе интерес к культуре собственной нации сочетается с большей информированностью о культуре приезжих. Акцент на культурной составляющей проявляется в характере требований к мигрантам, оценке факторов, объединяющих их с местным населением: так, здесь чаще, чем в других кластерах, выдвигается требование к мигрантам выполнять культурные нормы, принятые в России, а в качестве факторов, могущих объединить россиян и приезжих, более часто выдвигается владение одним языком.

Четвертый кластер - «равнодушные» (125 чел. - 25,8\%) - ориентирован на сохранение дистанции с выходцами из Центральной Азии (как в плане минимизации контактов, так и получения информации об этих народах). Установка на нейтралитет и удаленность среди представителей этого кластера проявляется и в небольшом числе требований к мигрантам. Кроме того, указывается меньшее число характеристик данных народов, которые могут влиять на отношение к ним со стороны россиян. Низкая информированность о приезжих проявляется не только в использовании минимального среди четырех анализируемых кластеров числа источников информации (таблица 3). Можно говорить и об отсутствии сформированного мнения по вопросам, связанным с приездом мигрантов на территорию города и увеличением их численности: так, на вопрос об отношении к приему нерусских мигрантов «равнодушные» продемонстрировали безразличное отношение к этому вопросу либо дали ответ «не знаю» (73 и 16\% соответственно), т.е. почти у 90\% опрошенных в этой классификационной группе четкая позиция по данному вопросу отсутствует. Похожая ситуация сложилась и при ответе на вопрос об отношении к росту числа мигрантов - 84\%. Несмотря на небольшое желание вводить мигрантов в круг близких людей, «равнодушные» почти в 70\% случаев не возражают против предоставления им гражданства, а в 38\% - утверждают, что вполне привыкли к присутствию в городе приезжих из Центральной Азии, причем такое отношение сочетается с ощутимым незнанием культуры данных национальных групп (более $80 \%$ опрошенных). 
Таблица 5. Показатели национально-культурных характеристик в кластерах, \% от числа опрошенных в каждом кластере

\begin{tabular}{|l|c|c|c|c|}
\hline \multirow{2}{*}{$\begin{array}{l}\text { Национально-культурные } \\
\text { характеристики }\end{array}$} & $\begin{array}{c}|c| \\
\text { КНеприми- } \\
\text { римые» }\end{array}$ & $\begin{array}{c}\text { «Действен- } \\
\text { ные благо- } \\
\text { желатели» }\end{array}$ & $\begin{array}{c}\text { «Противо- } \\
\text { речивые» }\end{array}$ & $\begin{array}{c}\text { «Равнодуш- } \\
\text { ные» }\end{array}$ \\
\cline { 2 - 5 } $\begin{array}{l}\text { Интересуется литературой на националь- } \\
\text { ном языке либо историей своего народа }\end{array}$ & 68,6 & 52,0 & 66,1 & 40,0 \\
\hline $\begin{array}{l}\text { Полностью согласен с утвержде- } \\
\text { нием «Я постоянно помню овоей } \\
\text { национальности» }\end{array}$ & 65,1 & 37,8 & 41,2 & 24,0 \\
\hline $\begin{array}{l}\text { Считает, что русская культура должна } \\
\text { занимать ведущее место в нашей стране }\end{array}$ & 84,0 & 66,7 & 75,7 & 64,0 \\
\hline $\begin{array}{l}\text { Некоторые национальности вызывают } \\
\text { неприязнь }\end{array}$ & 33,3 & 8,0 & 18,3 & 9,6 \\
\hline $\begin{array}{l}\text { Может отличить мигрантов хотя бы неко- } \\
\text { торых национальностей по внешнему виду }\end{array}$ & 40,5 & 64 & 60 & 26,4 \\
\hline $\begin{array}{l}\text { Знаком с культурными особенностями всех } \\
\text { или некоторых национальных групп: тад- } \\
\text { жиков, киргизов, узбеков, казахов, туркмен }\end{array}$ & 20,8 & 56,0 & 33,3 & 17,6 \\
\hline $\begin{array}{l}\text { Оценивает уровень культуры поведения } \\
\text { мигрантов как низкий }\end{array}$ & 57,1 & 1,3 & 23,5 & 13,0 \\
\hline $\begin{array}{l}\text { Никакие национальности не вызывают } \\
\text { неприязни }\end{array}$ & 13,1 & 66,7 & 40,9 & 35,2 \\
\hline $\begin{array}{l}\text { Не возражает против сохранения } \\
\text { мигрантами своей культуры }\end{array}$ & 28,6 & 65,3 & 44,3 & 40,8 \\
\hline
\end{tabular}

В кластере «равнодушных» так же, как и у «непримиримых», наблюдаются достаточно высокая социальная дистанция с мигрантами и низкая информированность об их культурных особенностях. Но концентрация на своей национальности, интерес к ценностям собственной культуры являются здесь тоже крайне слабыми. Поэтому дистанцирование от мигрантов связано не с обеспечением защитной культурной функции, как в кластере «непримиримых», а с культурным безразличием - как к культуре выходцев из Центральной Азии, так и отчасти к культуре собственной нации.

Следует подчеркнуть, что анализируемые кластеры имеют как сходство, так и различия по разным аспектам отношения к мигрантам. Остановимся отдельно на двух группах, имеющих максимальные отличия: кластеры «непримиримых» и «действенных благожелателей» являются противостоящими практически по всему комплексу индикаторов. По показателям отношения к мигрантам наибольшее различие между указанными группами достигает 80\% и относится к доле вполне привыкших к присутствию в городе жителей Центральной Азии. По национально-культурным характеристикам наивысшее расхождение - 53,6\%, оно касается доли считающих, что «никакие национальности не вызывают неприязни» ( таблищза 5). На наш взгляд, основное различие между данными группами - ценностное. Оно косвенно проявляется в наличии или отсутствии неприязни к некоторым нациям. Мы считаем, что 
в случае увеличения в Екатеринбурге числа мигрантов из Центральной Азии отношение к ним в этих кластерах существенно не изменится вследствие максимальной устойчивости ценностных ориентаций в системе диспозиций личности.

В целом можно говорить о том, что четыре выделенных кластера отличаются характером сочетания двух основных параметров: отношения к мигрантам на личностном уровне и на уровне миграции как социального процесса. «Непримиримые» как кластер характеризуются негативным отношением к мигрантам и на личностном уровне, и на уровне миграции как социального процесса. Для «действенных благожелателей» характерно положительное отношение к приезжим как на личностном, так и на социальном уровне. Представители «противоречивых» проявляют положительное отношение на личностном уровне, отрицательное на социальном. Для «равнодушных» свойственна другая ситуация: на личностном уровне отношение - критическое (что проявляется в высокой социальной дистанции), а на социальном в большинстве случаев зафиксировано безразличное либо неопределенное отношение к мигрантам.

Отметим, что в центре формирования негативного отношения к мигрантам среди «непримиримых» стоит ценностная диспозиция: концентрация внимания на собственной национальной принадлежности, наличие неприязни к некоторым национальностям. Можно говорить о существовании определенного предубеждения по отношению к мигрантам. Не исключено, что имеющаяся в данной группе низкая оценка культуры мигрантов и преобладающая отрицательная информация о них появились в связи с тем, что они подтверждают уже сложившиеся предубеждения [Кон 1961].

Положительное отношение к мигрантам «действенных благожелателей» базируется на уже сформировавшихся широких контактах с жителями Центральной Азии, в том числе и как с коллегами. Совместная работа рассматривается данной группой как обстоятельство, которое может являться существенным для нарастания «похожести» местных жителей и приезжих. Можно говорить об одобрении еще большего расширения трудовых контактов с мигрантами, готовности приспособления к их культуре через согласие меняться под влиянием новых культурных норм.

В кластере «противоречивых» выраженная готовность ввести мигрантов в круг близких людей, оказать помощь в решении отдельных проблем сочетается с отрицательными диспозициями относительно миграции как социального процесса. В их основе заложены экономические интересы: около 38\% опрошенных указали на то, что мигранты приносят экономические проблемы местному населению. Можно говорить о страхе данной группы за свое экономическое будущее в том случае, если потоки мигрантов будут увеличиваться.

Высокая социальная дистанция с народами Центральной Азии представителей кластера «равнодушных» обусловлена незначительным общением с мигрантами и низкой информированностью о них и их культуре. Культурное безразличие в данном случае проявляется не только по отношению к культуре выходцев из Центральной Азии, но и отчасти к культуре собственной нации.

Выделение типологических групп отношения жителей Екатеринбурга к иноэтничным мигрантам из стран Центральной Азии позволяет видеть не только остроту проблем взаимной интеграции местного населения и приезжих, но и прогнозировать развитие межнациональных взаимоотношений в регионе, что является актуальным для России в целом. 


\section{Перспективы развития представленной тематики}

Перспективы изучения данной проблематики могут быть связаны как с расширением географии проведения подобных исследований на территории Российской Федерации, так и с углублением анализа типологии жителей территории по отношению к иноэтничным мигрантам. В дальнейших исследованиях нуждаются многоуровневость социальной идентичности россиян и мигрантов и место этнокультурной идентичности в этой системе.

Особый аспект анализа, по нашему мнению, - это изучение видов и форм коммуникационных контактов россиян и мигрантов, влияние СМИ на их эффективность. Исследование коммуникационного поля региона показывает, что этнокультурные объединения стремятся стать активными субъектами массовой коммуникации с целью влияния на общественное мнение, однако формы и инструменты такого влияния зачастую дают обратный эффект по сравнению с запланированным, обостряя ситуацию в регионе.

Важным направлением дальнейшего изучения проблемы отношения к иноэтничным мигрантам, по нашему мнению, является и анализ информированности школьников и студентов о культуре народов, представителей которых больше всего среди внешних иноэтничных мигрантов.

\section{Литература}

Абашин С.Н. (2012) Среднеазиатская миграция: практики, локальные сообщества, транснационализм // Этнографическое обозрение. № 4. С. 3-13.

Бритвина И.Б., Киблицкая М.В. (2004) Жизнь мигрантки в моногороде. М.: Книгодел. Гудков Л.Д. (2007) Почему мы не любим приезжих? // Мир России. Т. 16. № 2. С. 48-82. Дробижева Л.М. (2017) Гражданская идентичность как условие ослабления этнического негативизма // Мир России. Т. 26. № 1. С. 7-31.

Кон И.С. (1961) Психология предрассудка (О социально-психологических корнях этнических предубеждений) // Новый мир. № 10. С. 187-205.

Кузнецов И.М. (2017) Баланс межнациональных установок как индикатор состояния межэтнических отношений // Мир России. Т. 26. № 1. С. 58-80.

Лапшина Т.В., Константинов В.В. (2016) Отношение к мигрантам представителей принимающего сообщества в зависимости от типа проживания мигрантов // Мир науки. T. 4. № 4 // http://mir-nauki.com/PDF/15PSMN416.pdf

Мигранты в России: эффекты присутствия // ВЦИОМ. Пресс-выпуск № 3254 // http://wciom.ru/index.php?id=236\&uid=115969

Мукомель В.И. (2011) Интеграция мигрантов: вызовы, политика, социальные практики // Мир России. Т. 20. № 1. С. 34-50.

Мукомель В.И. (2017) Ксенофобы и их антиподы: кто они? // Мир России. Т. 26. № 1. С. $32-57$. Пипия К. (2016) Интолерантность и ксенофобия // Левада-Центр // http://www.levada.ru/2016/10/11/intolerantnost-i-ksenofobiya

Политика «замещающей миграции» в России - последствия и альтернативы (2014) // Институт национальной стратегии // http://www.instrategy.ru/pdf/250.pdf

Санина А.Г. (2014) Генезис идеи идентичности в социологии и смежных науках // Социологические исследования. № 12. С. 3-11.

Федюкина К.А. (2015) Образ мигранта в массовом сознании жителей Красноярского края // Специфика этнических миграционных процессов на территории Центральной Сибири в XX-XXI веках: опыт и перспективы. Сб. материалов V Междунар. науч.- 
практ. конф. Красноярск: Сибирский федеральный университет // http://elib.sfu-kras. $\mathrm{ru} /$ bitstream/handle/2311/20945/fedyukina_obraz_migranta.pdf?sequence=1

Хантингтон С. (2004) Кто мы?: Вызовы американской национальной идентичности. М.: АСТ, Транзиткнига.

Ядов В.А. (1995) Социальные и социально-психологические механизмы формирования социальной идентичности личности // Мир России. № 3/4. С. 158-181.

Bessudnov A. (2016) Ethnic Hierarchy and Public Attitudes Towards Immigrants in Russia // European Sociological Review, vol. 32, no 5, pp. 567-580.

Grigoryan L. (2016) National Identity and Anti-immigrant Attitudes: The Case of Russia // Dynamics of National Identity: Media and Societal Factors of What We Are (eds. Grimm J., Huddy L., Schmidt P., Seethaler J.), London: Routledge, pp. 206-228.

Huntington S.P. (1996) The Clash of Civilizations and the Remaking of World Order, New York: Simon \& Schuster.

Karlsen S., Nazroo J.Y. (2015) Ethnic and Religious Differences in the Attitudes of People Towards Being 'British' // The Sociological Review, vol. 63, no 4, pp. 759-781.

Mierina I., Koroleva I. (2015) Support for Far Right Ideology and Anti-migrant Attitudes Among Youth in Europe: A Comparative analysis // The Sociological Review, vol. 63, no 2, pp. 183-205.

Ponizovskiy V.A. (2016) Values and Attitudes Towards Immigrants: Cross-cultural Differences Across 25 Countries // Психология. Журнал Высшей школы экономики. Т. 13. № 2. С. 256-272 (на англ. яз.).

Roblain A., Azzi A., Licata L. (2016) Why Do Majority Members Prefer Immigrants Who Adopt the Host Culture? The Role of Perceived Identification with the Host Nation // International Journal of Intercultural Relations, vol. 55, pp. 44-54.

Schröder Ph., Stephan-Emmrich M. (2016) The Institutionalization of Mobility: Well-being and Social Hierarchies in Central Asian Translocal Livelihoods // Mobilities, vol. 11, no 3, pp. 420-443.

Simpson J.J., Simpson P.M., Cruz-Milan O. (2016) Attitude Towards Immigrants and Security: Effects on Destination-loyal Tourists // Tourism Management, vol. 57, pp. 373-386.

Thieme S. (2008) Sustaining Livelihoods in Multi-local Settings: Possible Theoretical Linkages between Transnational Migration and Livelihood Studies // Mobilities, vol. 3, no 1, pp. 51-71// http://dx.doi.org/10.1080/17450100701797315

Waisman G., Larsen, B. (2016) Income, Amenities and Negative Attitudes // IZA Journal of Migration, vol. 5, no 8, pp. 1-32.

\title{
The Typology of Citizens of a Russian Megapolis According to their Attitudes to Migrants of Different Ethnicities
}

\author{
I. BRITVINA*, E. MOGILCHAK**
}

\begin{abstract}
*Irina Britvina - Doctor of Science in Sociology, Professor at the Department of Integrated Marketing Communications and Branding. Ural Federal University named after the first President of Russia B. N. Yeltsin. Address: 19, Mira St., Yekaterinburg, 620002, Russian Federation. E-mail: irina.britvina@urfu.ru

**Elena Mogilchak - Candidate of Sciences in Philosophy, Associate Professor. Ural Federal University named after the first President of Russia B. N. Yeltsin. Address: 19, Mira St., Yekaterinburg, 620002, Russian Federation. E-mail: e.1.mogilchak@urfu.ru
\end{abstract}

Citation: Britvina I., Mogilchak T. (2018) The Typology of Citizens of a Russian Megapolis According to their Attitudes to Migrants of Different Ethnicities. Mir Rossii, vol. 27, no 1, pp. 114-134 (in Russian). DOI: 10.17323/1811-038X-2018-27-1-114-134 


\section{Abstract}

This article examines the attitudes towards migrants of different ethnicities in a heterogenous host community as a factor of acculturation. The analysis is based on a survey of residents of Yekaterinburg aged 15 and above. The authors distinguish and describe four types of citizens based on their attitudes towards migrant workers from Central Asia - "uncompromising", "active well-wishers", "contradictory" and "indifferent". The typology was obtained from a cluster analysis of 12 items of the questionnaire. Each type is described in terms of specific manifestations of attitudes towards migrants, e.g. the admissibility of marital relationships with migrants, friendship and so forth. Two of the clusters represent highly polar groups, different in the degree of their hostility towards certain ethnic groups. The results of the survey also reveal that attitudes correlate highly with the level of interactions with migrants, awareness of the threats they pose to the economic interests of the locals, and ethnic indifference. In conclusion, the authors discuss specific causes of the formation of attitudes towards migrants in the identified clusters.

Key words: migration, the host society, acculturation, attitudes, values, interests, cluster analysis

\section{References}

Abashin S.N. (2012) Sredneaziatskaya migratsiya: praktiki, lokal'nye soobshchestva, transnatsionalizm [Migration from Central Asia: Practices, Local Communities, Transnationalism]. Etnograficheskoe obozrenie, no 4, pp. 3-13.

Bessudnov A. (2016) Ethnic Hierarchy and Public Attitudes towards Immigrants in Russia. European Sociological Review, vol. 32, no 5, pp. 567-580.

Britvina I.B., Kiblitskaya M.V. (2004) Zhizn' migrantki v monogorode [The Life of a Migrant Woman in the Monocity], Moscow: Knigodel, 2004.

Drobizheva L. (2017) Grazhdanskaya identichnost' kak uslovie oslableniya etnicheskogo negativizma [National Identity as a Means of Reducing Ethnic Negativism]. Mir Rossii, vol. 26, no 1 , pp. 7-31.

Fedyukina K.A. (2015) Obraz migranta v massovom soznanii zhitelej Krasnojarskogo kraya [The Image of a Migrant in the Mass Consciousness of Inhabitants of Krasnoyarsk Region]. Spetsifika etnicheskikh migratsionnykh protsessov na territorii Tsentral'noj Sibiri $v X X-X X I$ vekakh: opyt i perspektivy [The Specifics of Ethnic Migration in Central Siberia in the XX-XXI Centuries: Experience and Prospects], Krasnoyarsk: Sibirskij federal'nyj universitet. Available at: http://elib.sfu-kras.ru/bitstream/handle/2311/20945/fedyukina obraz_migranta.pdf? sequence $=1$, accessed 31 October 2017.

Grigoryan $\bar{L}$. (2016) National Identity and Anti-immigrant Attitudes: The Case of Russia. Dynamics of National Identity: Media and Societal Factors of What We Are (eds. Grimm J., Huddy L., Schmidt P., Seethaler J.), London: Routledge, pp. 206-228.

Gudkov L.D. (2007) Pochemu my ne lyubim priezzhikh? [Why Don’t We Like Visitors?]. Mir Rossii, vol. 16, no 2, pp. 48-82.

Huntington S. (2004) Kto my?: Vyzovy amerikanskoj natsional'noj identichnosti [Who Are We? The Challenges to America's National Identity], Moscow: AST, Tranzitkniga. 
Huntington S.P. (1996) The Clash of Civilizations and the Remaking of World Order, New York: Simon \& Schuster.

Karlsen S., Nazroo J.Y. (2015) Ethnic and Religious Differences in the Attitudes of People Towards Being 'British'. The Sociological Review, vol. 63 (4), pp. 759-781.

Kon I.S. (1961) Psikhologiya predrassudka (O sotsial'no-psikhologicheskikh kornyakh etnicheskikh predubezhdenij) [The Psychology of Prejudice (Socio-psychological Roots of Ethnic Prejudice)]. Novyj mir, no 10, pp. 187-205.

Kuznetsov I.M. (2017) Balans mezhnatsional'nykh ustanovok kak indikator sostoyaniya mezhetnicheskikh otnoshenij [The Balance of Interethnic Attitudes as an Indicator of State of Interethnic Relations]. Mir Rossii, vol. 26, no 1, pp. 58-80.

Lapshina T.V., Konstantinov V.V. (2016) Otnoshenie k migrantam predstavitelej prinimayushchego soobshchestva $\mathrm{v}$ zavisimosti ot tipa prozhivaniya migrantov [Treatment of Migrants by the Host Community Depending on the Type of Accommodation of Migrants]. Mir nauki, vol. 4, no 4. Available at: http://mir-nauki.com/PDF/15PSMN416.pdf, accessed 31 October 2017.

Mierina I., Koroleva I. (2015) Support for Far Right Ideology and Anti-migrant Attitudes Among Youth in Europe: A Comparative Analysis. The Sociological Review, vol. 63, no 2, pp. 183-205.

Migrantyv Rossii: effekty prisutstviya(2016) [The Effects of Migrants'Presence in Russia]. VCIOM. Press Release, no 3254. Available at: http://wciom.ru/index.php?id=236\&uid=115969, accessed 31 October 2017.

Mukomel V.I. (2011) Integratsiya migrantov: vyzovy, politika, sotsial'nye praktiki [Integration of Migrants: Challenges, Policies, Social Practices]. Mir Rossii, vol. 20, no 1, pp. 34-50.

Mukomel V.I. (2017) Ksenofoby i ikh antipody: kto oni? [Xenophobes and Their Opposites: Who Are They?]. Mir Rossii, vol. 26, no 1, pp. 32-57.

Pipiya K. (2016) Intolerantnost' i ksenofobiya [Intolerances and Xenophobia]. Levada-Center. Available at: http://www.levada.ru/2016/10/11/intolerantnost-i-ksenofobiya, accessed 31 October 2017.

Politika “zameshchayushchej migratsii" v Rossii - posledstviya i al'ternativy (2014) [The Policy of Substituting Migration in Russia - Consequences and Alternatives]. Institute of National Strategy. Available at: http://www.instrategy.ru/pdf/250.pdf, accessed 31 October 2017.

Ponizovskiy V.A. (2016) Values and Attitudes Towards Immigrants: Cross-cultural Differences Across 25 Countries. Psychology. Journal of the Higher School of Economics, vol. 13, no 2, pp. 256-272.

Roblain A., Azzi A., Licata L. (2016) Why Do Majority Members Prefer Immigrants Who Adopt the Host Culture? The Role of Perceived Identification with the Host Nation. International Journal of Intercultural Relations, vol. 55, pp. 44-54.

Sanina A.G. (2014) Genezis idej identichnosti v sotsiologii i smezhnykh naukakh [The Genesis of Identity Idea in Sociology and Adjacent Sciences]. Sotsiologicheskie issledovaniya, no 12 , pp. 3-11.

Schröder Ph., Stephan-Emmrich M. (2016) The Institutionalization of Mobility: Well-being and Social Hierarchies in Central Asian Translocal Livelihoods. Mobilities, vol. 11, no 3, pp. 420-443.

Simpson J.J., Simpson P.M., Cruz-Milan O. (2016) Attitude Towards Immigrants and Security: Effects on Destination-loyal Tourists. Tourism Management, vol. 57, pp. 373-386.

Thieme S. (2008). Sustaining Livelihoods in Multi-local Settings: Possible Theoretical Linkages Between Transnational Migration and Livelihood Studies. Mobilities, vol. 3, no 1, pp. 51-71. Available at: http://dx.doi.org/10.1080/17450100701797315, accessed 31 October 2017.

Waisman G., Larsen, B. (2006) Income, Amenities and Negative Attitudes. IZA Journal of Migration, vol. 5, no 8, pp. 1-32.

Yadov V.A. (1995). Sotsial'nye i sotsial'no-psikhologicheskie mekhanizmy formirovaniya sotsial'noj identichnosti lichnosti [Social and Socio-psychological Mechanisms of Formation of Social Identity]. Mir Rossii, no 3/4, pp. 158-181. 